Vol. 18 (2009): 332-346.

\title{
Energy ratios in Finnish agricultural production
}

\author{
Hannu J. Mikkola* and Jukka Ahokas \\ Department of Agrotechnology, University of Helsinki, PO Box 28, \\ FI-00014 University of Helsinki, Finland \\ *email: hannu.j.mikkola@helsinki.fi
}

\begin{abstract}
The objective of this study was to assess energy ratios and net energy in plant production and energy ratios in animal production in Finland. Energy ratios and net energy were determined on the basis of plant- and animal-specific energy analyses.

In plant production, energy ratios and net energy were assessed as a function of nitrogen fertilization, because indirect energy input in the form of agrochemicals was $54-73 \%$ from the total energy input and nitrogen was responsible for the major part of this. The highest energy ratio was 18.6 for reed canary grass. As a whole reed canary grass was superior to the other crops, which were barley, spring wheat, spring turnip rape, ley for silage, potato and sugar beet. Reed canary grass and sugar beet gained the highest net energy yields of $111-115 \mathrm{GJ} \mathrm{ha}^{-1}$. The optimum energy ratio was gained in general with less nitrogen fertilization intensity than farmers use.

The energy ratios in pork production varied between $0.14-1.28$ depending on what was included or excluded in the analysis and for milk production between $0.15-1.85$. Ratios of 1.28 in pork production and 1.85 in milk production are unrealistic as they do not give any shelter to the animals, although they can be approached in very low-input production systems. If the ratio is calculated with feed energy content then the ratio is low, $0.14-0.22$ for pork and 0.15 for milk. This shows that animals can convert 14-22 percent of the input energy to usable products. In pork production, the largest portion of the energy input was the ventilation of the building. In milk production milking and cooling consumes a lot of energy and for this reason the electricity consumption is high.
\end{abstract}

Key-words: energy, energy ratio, plant production, animal production 
Vol. 18 (2009): 332-346.

\section{Introduction}

This paper assesses energy ratios in Finnish agricultural production. Energy ratio is a concept used to describe the relationship between the energy output of a system and the energy inputs needed to operate the system. Energy ratio can be expressed as $E R=$ $E_{o} / E_{i}$, where ER is energy ratio, $\mathrm{E}_{\mathrm{o}}$ is energy output and $E_{i}$ is energy input. Energy ratio is determined on the basis of an energy analysis.

Finland is the northernmost country in the world producing the major part of its own foodstuff. Due to the high latitude, and the hence often unfavorable agricultural climatic conditions, it is challenging to get high energy ratios in agricultural production. The growing season is short and intensive and most field operations have to be done in a short period of time due to timeliness effect, so high field-work capacity is needed. The harvesting season in the autumn is often rainy and harvested grain has to be dried every year. An average moisture content over years at harvesting time is $19 \%$ for barley and $21 \%$ for wheat (Sieviläinen 2008). The highest grain yields in farm conditions are 7-9 tons per hectare but the average yields are between 2.5-4.0 tons (TIKE 2007). A high energy ratio would require high dry matter yields with a low energy input.

In animal production, buildings must have better thermal insulation than in more southern regions. Heating is needed very often in animal houses during the cold period increasing energy demand. Many animals thrive in temperatures below zero but animal keepers prefer mild and undraughty working conditions, so farmers favor warm animal houses. Cold weather introduces its own problems in cattle barns. If the temperature falls below zero, problems with water supply and manure removal may occur. Milking has always to be performed in warm buildings.

In respect of energy ratios, there is evidently only one advantage due to location in the north. The pressure of plant pathogens and insects is lower and less plant protection is needed. Precipitation would be another advantage but it is mistimed. Drought is a usual problem in spring and heavy rains at harvesting time make harvesting difficult and increase the need of grain drying. Irrigation would be beneficial for many plants but it is economical only for high-value crops such as strawberries, vegetables and potatoes.

Energy ratios of bioenergy crops are today under critical assessment because biofuels must prove their friendliness for the environment. Reed canary grass is seen in Finland as the best potential energy crop for field energy production, but comparable research on the energy ratio of other crops has been missing. This research compares the most common crops with reed canary grass and tests energy ratios against given fertilization recommendations. Nitrogen is an important growth factor, but the manufacture of nitrogen fertilizer consumes a great deal of energy and releases a great deal of greenhouse gas.

Animal production is economically important for Finnish agriculture. It is known on a general level that plant production has a better energy balance, but this research gives more accurate information from the ratio of plant and animal production. Human nutrition is composed of plant and animal products. Energy ratio is an environmental indicator that consumers can use when they make their daily foodstuff shopping decisions.

Energy ratios for Finnish plant and animal production have not been reported systematically earlier. It is possible to calculate energy ratios for barley and reed canary grass, e.g., from the report of Mäkinen et al. (2006), but this report concentrates more on transport biofuels than on energy ratios. Giampietro (2004) has presented energy ratios in terms of food production in developed and developing counties, but he does not present energy ratios for individual plant or animal products. Several LCA analyses of Finnish agricultural products include also energy analysis (Katajajuuri et al. 2000, Voutilainen et al. 2003a, Voutilainen et al. 2003b, Katajajuuri et al. 2003, Grönroos et al. 2006). 
Mikkola, H. J. \& Ahokas, J. Energy ratios in Finnish agricultural production

\section{Materials and methods}

\section{Plant production}

Energy ratios were assessed on different nitrogen fertilization rates for barley (Hordeum vulgare L.), spring wheat (Triticum aestivum L.), spring turnip rape (Brassica rapa ssp. oleifera (DC) Metsg.), reed canary grass (Phalaris arundinacea L.) and ley for silage (a mixture of Phleum pratense L. and Festuca pratensis Huds.), by using functions for nitrogen response, (Table 1). Energy ratios for potato (Solanum tuberosum L.) and sugar beet (Beta vulgaris L.) were assessed only on optimal nitrogen intensity because nitrogen response functions were not available for these plants. Optimal nitrogen intensity meant in these cases an average recommended application rate in terms of high quality and reasonable yield, namely $70 \mathrm{~kg} \mathrm{ha}^{-1}$ for potato and $120 \mathrm{~kg} \mathrm{ha}^{-1}$ for sugar beet.

Nitrogen response functions for barley, spring wheat and spring turnip rape were derived from Hildén et al. (2007). These functions were based on yield data from experimental plots. They resulted in considerably higher yields than averages in the period 1990-2006 (Yearbook of farm statistics 2007). So the functions were scaled to accord with average yields. Nitrogen response function for reed canary grass was formulated on the basis of the data of Saijonkari-Pahkala (2001). Also this yield data originated from experimental plots and the yield was corrected $25 \%$ downwards because of the outstanding harvesting losses in hands-on production reported by Lindh et al. (2007). Losses may be even $40-50 \%$, but with advanced harvesting technique and careful work it is possible to lower them to 20-25\% (Lötjönen 2008). The nitrogen response function for ley for silage was derived from Hiivola et al. (1974) and it was used without corrections, since ley yields generated with this function were in line with yields harvested in practical conditions. Figure 1 presents nitrogen response curves for the scaled or corrected functions presented in Table 1.

Energy consumption for cultivation was analyzed by using models tailored for each crop. These models contained relevant stages of production chains and took into account both direct energy input in the form of liquid fuels and electricity used for tractors and grain drying, and indirect energy embodied in machines (production + maintenance), chemicals, seeds and other necessary goods. Energy input was converted to primary energy if an energy item was identified to be secondary energy. However, it was not possible to use primary energy

Table 1. Original and scaled nitrogen response functions for barley, spring wheat, reed canary grass and ley for silage.

\begin{tabular}{|c|c|c|c|c|}
\hline Crop & $\begin{array}{l}\text { Moisture } \\
\text { content, } \\
\text { \% w.b. }\end{array}$ & Nitrogen response function & Source & Scaled function \\
\hline Barley & 15 & $\mathrm{y}=-0.1305 \mathrm{~N}^{2}+35.697 \mathrm{~N}+3275$ & $\begin{array}{l}\text { Hildén et al. } \\
2007\end{array}$ & $\mathrm{y}=-0.1305 \mathrm{~N}^{2}+35.697 \mathrm{~N}+1275$ \\
\hline Spring wheat & 15 & $\mathrm{y}=-0.089 \mathrm{~N}^{2}+32.33 \mathrm{~N}+2536$ & $\begin{array}{l}\text { Hildén et al. } \\
2007\end{array}$ & $\mathrm{y}=-0.089 \mathrm{~N}^{2}+32.33 \mathrm{~N}+1387$ \\
\hline Spring turnip rape & 9 & $\mathrm{y}=-0.026 \mathrm{~N}^{2}+12.57 \mathrm{~N}+1034$ & $\begin{array}{l}\text { Hildén et al. } \\
2007\end{array}$ & $\mathrm{y}=-0.026 \mathrm{~N}^{2}+12.57 \mathrm{~N}+627$ \\
\hline Reed canary grass & 0 & $\mathrm{y}=-0.1137 \mathrm{~N}^{2}+38.703 \mathrm{~N}+6172$ & 1) & $\mathrm{y}=-0.0853 \mathrm{~N}^{2}+29.028 \mathrm{~N}+4628.9$ \\
\hline \multirow[t]{4}{*}{ Ley for silage } & 0 & 1. cut: & Hiivola et & 1. cut: \\
\hline & & $\mathrm{y}=-0.084 \times \mathrm{N}^{2}+26.9 \times \mathrm{N}+992$ & al. 1974 & $\mathrm{y}=-0.084 \times \mathrm{N}^{2}+26.9 \times \mathrm{N}+992$ \\
\hline & & 2. cut: & & 2. cut: : \\
\hline & & $\mathrm{y}=-0.098 \times \mathrm{N}^{2}+28.73 \times \mathrm{N}+764$ & & $\mathrm{y}=-0.098 \times \mathrm{N}^{2}+28.73 * \mathrm{~N}+764$ \\
\hline
\end{tabular}

\footnotetext{
1) The authors have derived this function on the basis of the yield data of Saijonkari-Pahkala 2001.
} 
Vol. 18 (2009): 332-346.
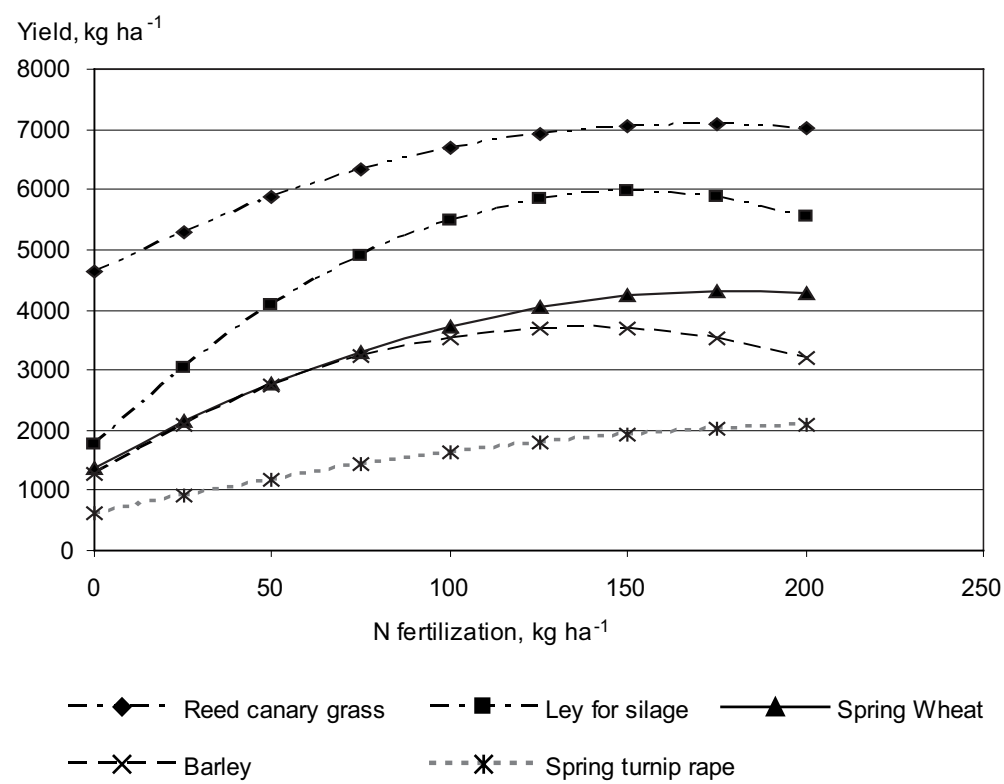

Fig. 1. Scaled or corrected nitrogen response functions for barley, spring wheat, reed canary grass and ley for silage. Moisture content of the crop, $\%$ on wet basis: barley and spring wheat $15 \%$, spring turnip rape $9 \%$, reed canary grass and ley for silage $0 \%$ (dry matter). systematically because reports did not always tell whether an energy item was secondary or primary energy. This problem was related especially to indirect energy input. The method of Mikkola and Ahokas (2008) was used to count indirect energy embodied in machines. Energy for human labour and energy for making buildings was considered to be outside the system. Table 2 presents the most important starting values of input energy used in the models.

Figure 2 presents the distribution of energy input in barley, ley and sugar beet cultivation. The category "Agrochemicals" includes fertilizers, lime, pesticides and additive used in ley silage production. Fertilizers, and especially nitrogen manufacturing dominated the input energy. Pesticides also had an outstanding share in sugar beet production. The nitrogen fertilization rate was $80 \mathrm{~kg}$ $\mathrm{ha}^{-1}$ for barley, $180 \mathrm{~kg} \mathrm{ha}^{-1}$ for ley and $120 \mathrm{~kg} \mathrm{ha}^{-1}$ for sugar beet. The category "Machines and fuel" covered the technical energy input, i.e. machine production, repair and maintenance and diesel fuel consumption. In Figure 2 there are also two crop specific categories, "Grain drying" and "Wrapping plastic". Figure 2 shows that ley and sugar beet cropping are more energy intensive than barley cropping in terms of $\mathrm{MJ} \mathrm{ha}^{-1}$.

Energy output was defined as the lower heating value (LHV) of the dry matter of the crop. This procedure does not take into account the physical state of the crop and so Table 3 presents the location and state of the yield at the end of the analyzed production chain. Net energy was the subtraction of energy output and energy input.

The impact of different soil tillage practices on the energy ratios of barley, spring wheat and spring turnip were also assessed. Ploughing was a reference method and it was compared with stubble cultivation and direct drilling.

\section{Pork and milk production}

The energy balance in pork and milk production is calculated at farm level starting from the energy used in the feed material production and ending with the meat or milk that is sold from the farm. Feed, water, shelter and care are the inputs to the system and pork, milk, heat, gases, manure and waste are the outputs. The farmer takes care of the nutrition 


\section{Mikkola, H. J. \& Ahokas, J. Energy ratios in Finnish agricultural production}

Table 2. The most important starting values of input energy used in the models.

\begin{tabular}{|c|c|c|c|}
\hline $\begin{array}{l}\text { Operation of the production chain or } \\
\text { material input }\end{array}$ & $\begin{array}{l}\text { Diesel fuel } \\
\text { or energy } \\
\text { consumption }\end{array}$ & Unit & Sources \\
\hline \multicolumn{4}{|l|}{ Primary tillage } \\
\hline ploughing & 25.1 & 1 diesel per ha & $1,2,3,4,7$ \\
\hline \multicolumn{4}{|l|}{ stubble cultivation (one-pass) } \\
\hline tine & 10.0 & 1 diesel per ha & 3 \\
\hline disc & 7.2 & 1 diesel per ha & 1,7 \\
\hline \multicolumn{4}{|l|}{ Secondary tillage } \\
\hline $\begin{array}{l}\text { levelling of ploughed or stubble cul- } \\
\text { tivated soil }\end{array}$ & 4.5 & 1 diesel per ha & 2 \\
\hline harrowing (one-pass) & 5.4 & 1 diesel per ha & $1,2,3,4$ \\
\hline \multicolumn{4}{|l|}{ Seeding } \\
\hline combined seeding and fertilizing & 3.7 & 1 diesel per ha & 2,3 \\
\hline direct drilling & 7.6 & 1 diesel per ha & 1,3 \\
\hline Fertilizer spreading & 2.9 & 1 diesel per ha & 1,4 \\
\hline Spraying & 1.8 & 1 diesel per ha & $1,2,3,4$ \\
\hline Combine harvesting & 15.1 & 1 diesel per ha & $1,2,5$ \\
\hline Grain drying & 120.0 & ( $\mathrm{g}$ diesel oil) per $1 \mathrm{~kg} \mathrm{H} \mathrm{H}_{2} \mathrm{O}$ evaporated & 6 \\
\hline Mowing & 6.0 & 1 diesel per ha & 1,4 \\
\hline Baling (round bales) & 0.5 & 1 diesel per bale & 1 \\
\hline Field transport & 76.0 & ( $\mathrm{g}$ diesel oil) per ton and $\mathrm{km}$ & 1 \\
\hline Nitrogen & 49.2 & $\mathrm{MJ} \mathrm{kg-1}$ & 8 \\
\hline Phosphorous as $\mathrm{P}_{2} \mathrm{O}_{5}$ & 15.5 & $\mathrm{MJ} \mathrm{kg}^{-1}$ & 8 \\
\hline Potassium as $\mathrm{K}_{2} \mathrm{O}$ & 9.7 & $\mathrm{MJ} \mathrm{kg}^{-1}$ & 8 \\
\hline Pesticide & 273.6 & $\mathrm{MJ} \mathrm{kg}^{-1}$ & 8 \\
\hline Lime & 1.3 & $\mathrm{MJ} \mathrm{kg}^{-1}$ & 9 \\
\hline
\end{tabular}

\section{Sources:}

${ }^{1)}$ Ermittlung des Kraftstoffverbrauchs in der Land- und Forstwirtschaft 2005. Österreichisches Kuratorium für Landtechnik und Landentwicklung.

${ }^{2)}$ Palonen, J. \& Oksanen, E. H. 1993

3) Danfors, B. 1988. (N.B. Fuel consumption is multiplied with 1.2 in order take into account driving at headland.)

4) Rinaldi, M., Erzinger, S., \& Stark, R. 2005

5) Kalk, W.-D. \& Hülsbergen, K.-J. 1999

6) Suomi, P., Lötjönen, T., Mikkola, H., Kirkkari, A.-M., \& Palva, R. 2003.

7) McLaughlin, N. B., Drury, C. F., Reynolds, W. D., Yang, X. M., L, Y. X., Welacky, T. W. \& Stewart, G. 2008

${ }^{8)}$ Edwards, R., Larivé, J.-F., Mathieu, V. \& Rouveirolles, P. 2006

${ }^{9}$ Helsel, Z. R. 1992, Börjesson, P. I. I. 1996, West, T., O. \& Marland, G. 2002

of the animal as well as their living conditions and care. The animal produces not only the saleable product but also manure, heat and gases, and the manure the farmer can utilize as a fertilizer. Heat is utilized automatically as a heat source during cold periods but during warm periods excess heat must be ventilated from the building. Gases and manure contribute to environmental emissions. In this study, only the energy usage and balance are calculated at the farm level. To get the pork or milk to the consumer's table, more energy is used for transport and manufacturing, and the energy efficiency is much lower then than at the farm level. 
Vol. 18 (2009): 332-346.

Table 3. The state and place of the yield at the end of the harvesting chain.

\begin{tabular}{|c|c|c|c|c|}
\hline Crop & $\begin{array}{l}\text { Harvested } \\
\text { yield }\end{array}$ & $\begin{array}{l}\text { Moisture content } \\
\text { at the end of the } \\
\text { harvesting chain, } \\
\% \text { on wet basis }\end{array}$ & $\begin{array}{l}\text { LHV for dry } \\
\text { matter, } \mathrm{MJ} \mathrm{kg}^{-1}\end{array}$ & $\begin{array}{l}\text { Location and state of the crop at the end of } \\
\text { the harvesting chain }\end{array}$ \\
\hline Barley & Grains & 14 & 18.7 & On farm, in a silo. \\
\hline Spring wheat & Grains & 14 & 18.7 & On farm, in a silo. \\
\hline Spring turnip rape & Seeds & 9 & 26.4 & On farm, in a silo. \\
\hline Reed canary grass & Whole crop & 15 & 17.6 & $\begin{array}{l}\text { Round bales piled at the field edge. } \\
\text { Protected from rain. }\end{array}$ \\
\hline Grass for silage & Whole Crop & 68 & 17.6 & $\begin{array}{l}\text { Round bales wrapped with plastic at the } \\
\text { field edge. Additive used for conservation. }\end{array}$ \\
\hline Potato & Tubers & 77 & 18.7 & In a stack at the field edge. \\
\hline Sugar beet & Roots & 78 & 18.7 & In a stack at the field edge. \\
\hline
\end{tabular}

Barley, 11.6 $\mathrm{GJ} \mathrm{ha}^{-1}$ total

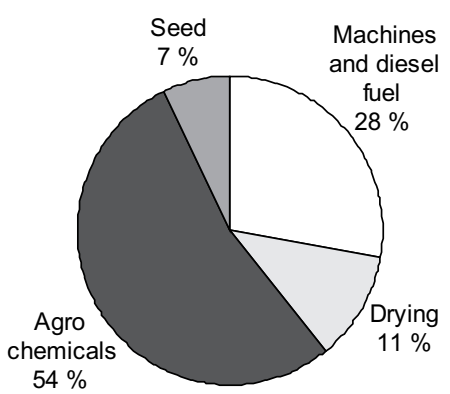

Ley for silage, $15.5 \mathrm{GJ} \mathrm{ha}^{-1}$ total

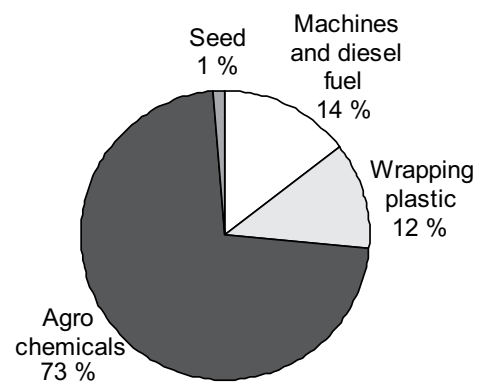

Sugar beet, $18.2 \mathrm{GJ} \mathrm{ha}^{-1}$ total

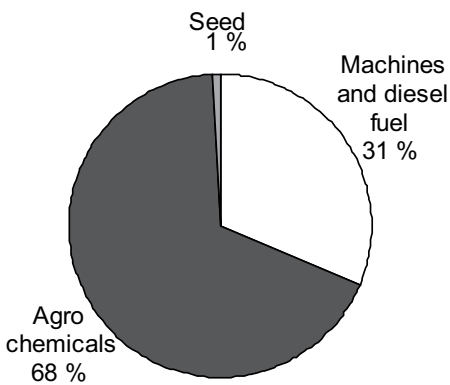

Fig. 2. Distribution of input energy in barley, ley and sugar beet cultivation.

The lifetime of the pig in pork production is approximately 15 weeks (MTT 2006) and the main feed is barley. During this time the energy intake of the animal is 2200-2400 MJ and the live weight of the animal before slaughter is $100-110 \mathrm{~kg}$ (MTT 2006). In the calculations, a value of $2300 \mathrm{MJ}$ is used for the feed intake energy value per animal, corresponding to $259 \mathrm{~kg}$ of barley, a live weight of $105 \mathrm{~kg}$. The energy used in barley production was calculated using figures from plant production, normally $9 \mathrm{GJ} \mathrm{ha}^{-1}$, and hence the growing of one pig requires $694 \mathrm{MJ}$ energy in the feed production. Besides barley, protein concentrates also are normally used for feeding pigs. Cederberg and
Darelius (2001) give a figure of $50 \mathrm{MJ} \mathrm{t}^{-1}$ energy usage in the manufactured concentrates whereas Gönroos and Voutilainen (2001) give $750 \mathrm{MJ} \mathrm{t}^{-1}$ for the manufacture of rape seed based concentrates. The energy used in rape production is $8091 \mathrm{MJ} \mathrm{t}^{-1}$ so the energy input in concentration adds $1-9 \%$ to this value and transport to and from the factory further increases this figure. If the transport distances are short and the concentrate usage is small, the amounts of concentrate do not have as much effect on the feed energy input as on the feed itself. For this reason, the input is calculated using only barley as feed. Swine manure can be utilized as fertilizer 


\section{Mikkola, H. J. \& Ahokas, J. Energy ratios in Finnish agricultural production}

in crop production, but this has not been taken into account in the analysis.

For milk production, the analysis was based on an annual production of $9000 \mathrm{~kg}$ per cow. The feed needed for this was calculated using the Finnish feeding recommendations (MTT 2006) and corresponds to 69 GJ per year. The feed consisted of hay silage $(60 \%)$ and concentrate $(40 \%)$ mixed at the farm, and only a minor amount of commercial feed was used. The energy content of the mix was calculated using feed material tables (MTT 2006) and it had energy of $11.7 \mathrm{MJ} \mathrm{kg}^{-1}$. The energy used in the feed production was calculated using figures from plant production and the mixing during production required $2.8 \mathrm{MJ} \mathrm{kg}^{-1}$ of energy. A cow produces, besides milk, calves and meat. The feed energy usage and energy used in milk production is in this study allocated into two parts so that 90 $\%$ is allocated for milk and the rest for meat and calf production.

The analysis includes only the direct energy consumption. Indirect energy input, for instance energy needed to construct the building and manufacture livestock machinery, are not included. The energy needed in housing is calculated from the regulations and instructions given by the Ministry of Agriculture and Forestry in Finland (MMM RMO 2002) and instructions for calculating the heating power and energy consumptions of buildings given by the Ministry of Environment (Ympäristöministeriö 2007). The calculations were done for Central Finland.

The calculations were done for milk and pork production for a housing of 100 animals and from these figures the specific consumption per animal was derived. The energy consumptions calculations included heat flows through walls, floor, ceiling, doors and windows and heat loss due to ventilation. The figures used in calculations are shown in tables 4 and 5 and they were taken from the recommendations of authorities (MMM RMO-C2.2 2002). Sun radiation was not included because during the heating period its effect is very low. First the outdoors balance temperature was calculated from the building heat balance. This temperature gives the starting point of the heating period. In all calculations the indoors temperature was kept con- stant as recommended by the authorities (MMM RMO-C2.2 2002). In practice heating demand could be reduced by lower indoor temperatures. The heating energy was calculated using outdoor temperature accumulation function, i.e. the time in days of outdoor temperatures below the outdoor balance temperature.

The energy needed for feeding and manure removal is taken from a survey of milking cows (Hörndahl 2007) and for pork production the figures were adjusted to meet the animal size using manure production as reference. The operating principles of feeding and manure removal machinery are same, and in this way their specific energy consumptions are similar in both types of production. Ventilation and illumination running energy usage was calculated from the recommended illumination and ventilation values (MMM RMO-C2.2 and MMM RMO-C3 2002). The main calculation values are given in Tables 4 and 5 .

Table 4. Values used in pork production analysis.

\begin{tabular}{|c|c|}
\hline Type of production & Continuous \\
\hline Animal density & 0.6 animals per $\mathrm{m}^{2}$ \\
\hline Growing period & 15 weeks \\
\hline \multicolumn{2}{|l|}{ Ventilation } \\
\hline - air flow & $25 \mathrm{~m}^{3} \mathrm{~h}^{-1}$ per animal \\
\hline - pressure & $20 \mathrm{~Pa}$ \\
\hline Sensible heat loss & $0.11 \mathrm{~kW}$ per animal \\
\hline \multicolumn{2}{|l|}{ U-values } \\
\hline - walls & $0.40 \mathrm{~W} \mathrm{~m}^{-2} \mathrm{~K}^{-1}$ \\
\hline - ceiling & $0.26 \mathrm{~W} \mathrm{~m}^{-2} \mathrm{~K}^{-1}$ \\
\hline - openings (doors and windows) & $3.00 \mathrm{~W} \mathrm{~m}^{-2} \mathrm{~K}^{-1}$ \\
\hline - floor & $0.60 \mathrm{~W} \mathrm{~m}^{-2} \mathrm{~K}^{-1}$ \\
\hline Location & Central Finland \\
\hline Heating degree day & $3702{ }^{\circ} \mathrm{C} \times \mathrm{d}$ \\
\hline Inside temperature & $16^{\circ} \mathrm{C}$ \\
\hline Illumination electric power & $3 \mathrm{~W} \mathrm{~m}^{-2}$ \\
\hline
\end{tabular}


Vol. 18 (2009): 332-346.

Table 5. Values used in milk production analysis.

\begin{tabular}{|c|c|}
\hline Type of housing & Warm loose housing \\
\hline Animal density & 0.13 animals per $\mathrm{m}^{2}$ \\
\hline Lactation period & 10 months \\
\hline \multicolumn{2}{|l|}{ Ventilation } \\
\hline - air flow & $150 \mathrm{~m}^{3} \mathrm{~h}^{-1}$ per animal \\
\hline - pressure & $20 \mathrm{~Pa}$ \\
\hline Sensible heat loss & $0.8 \mathrm{~kW}$ per animal \\
\hline \multicolumn{2}{|l|}{ U-values } \\
\hline - walls & $0.40 \mathrm{~W} \mathrm{~m}^{-2} \mathrm{~K}^{-1}$ \\
\hline - ceiling & $0.26 \mathrm{~W} \mathrm{~m}^{-2} \mathrm{~K}^{-1}$ \\
\hline - openings (doors and windows) & $3.00 \mathrm{~W} \mathrm{~m}^{-2} \mathrm{~K}^{-1}$ \\
\hline - floor ( $1 \mathrm{~m}$ area at the circumstance of the building) & $0.60 \mathrm{~W} \mathrm{~m}^{-2} \mathrm{~K}^{-1}$ \\
\hline Location & Central Finland \\
\hline Heating degree day & $2310^{\circ} \mathrm{C} \times \mathrm{d}$ \\
\hline Inside temperature & $12^{\circ} \mathrm{C}$ \\
\hline Illumination electric power & $5 \mathrm{~W} \mathrm{~m}^{-2}$ \\
\hline Milking and milk cooling energy consumption & $380 \mathrm{kWh}$ per cow and year ${ }^{1)}$ \\
\hline Feeding energy consumption & $400 \mathrm{kWh}$ per cow and year ${ }^{1)}$ \\
\hline Water pump energy consumption & $20 \mathrm{kWh}$ per cow and year $\left.{ }^{2}\right)$ \\
\hline Manure removal energy consumption & $30 \mathrm{kWh}$ per cow and year ${ }^{1)}$ \\
\hline Hot water energy consumption & $230 \mathrm{kWh}$ per cow and year ${ }^{2)}$ \\
\hline Allocation of energy to milk production & $90 \%$ \\
\hline
\end{tabular}

1) Hörndahl 2007, 2) Posio 2009

\section{Results}

\section{Plant production}

Energy ratios and net energy yields for the assessed crops are presented in Figure 3. Figure 4 presents the energy ratio of reed canary grass compared with those of potato and sugar beet.

Energy ratios for stubble cultivation and direct drilling are not reported. They were typically $9-12 \%$ higher than those for ploughing. Direct drilling of spring turnip rape increased the energy ratio $16-22 \%$.

Börjesson (1996) performed energy analysis in Sweden for potential energy crops with a corresponding method as used here. He reported that energy ratios and net energy yields were in the weather and yield conditions of 1996 for wheat 5.2 and $76 \mathrm{GJ} \mathrm{ha}^{-1}$, for rape seed 4.4 and $54.2 \mathrm{GJ} \mathrm{ha}^{-1}$, for clover-grass ley 11.0 and $127 \mathrm{GJ} \mathrm{ha}^{-1}$, for potato
3.0 and 86.6 $\mathrm{GJ} \mathrm{ha}^{-1}$, for sugar beet 7.0 and $163 \mathrm{GJ}$ $\mathrm{ha}^{-1}$, and for reed canary grass 11.0 and $109 \mathrm{GJ}$ ha $^{-1}$. In principal Börjesson (1996) has concluded some higher energy ratios and net energy yields than in this report. The difference is easy to understand due to more favorable growing conditions and higher yields in the major agricultural region in Sweden. Conforti and Giampietro (1997) have assessed energy use for crop production systems on a national level and concluded that energy ratio in 1990-1991 in Finland was 0.96 and in Sweden 1.96. On the basis of the present results the energy ratio in Finland has to be higher and close to the energy ratio for Sweden.

\section{Pork and milk production}

At slaughter, edible meat and internal organs represent $58 \%$ of the living weight (Lehto 2008). In the 


\section{Mikkola, H. J. \& Ahokas, J. Energy ratios in Finnish agricultural production}

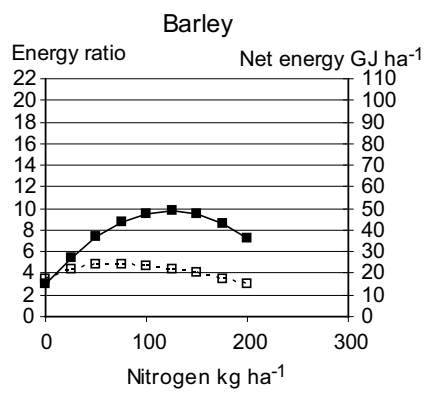

Reed canary grass

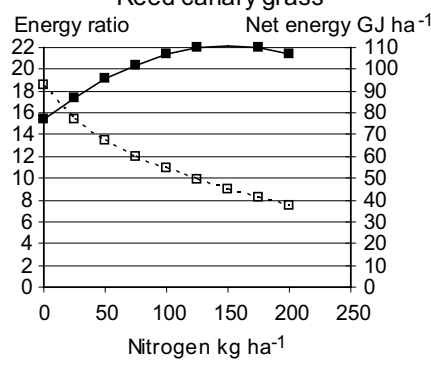

Spring wheat

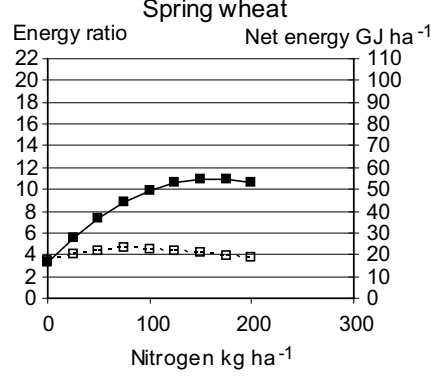

Ley for silage

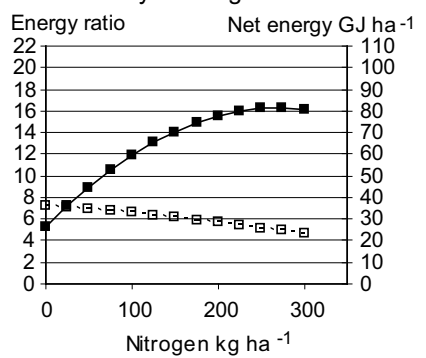

Spring turnip rape

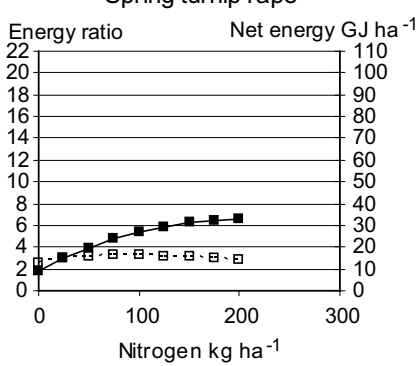

........ Energy ratio

—-Net energy, GJ/ha

Fig. 3. Energy ratios and net energy for barley, spring wheat, spring turnip rape, reed canary grass and ley for silage.

Potato and sugar beet compared with reed canary grass

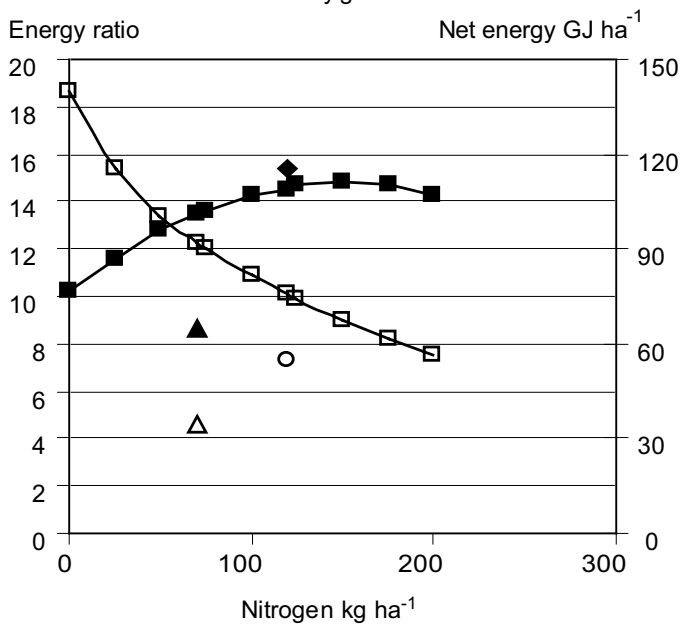

\section{$\square$ RCG/ Energy ratio \\ $\Delta$ Potato/ Energy ratio \\ - Sugar beet/ Energy ratio \\ $\longrightarrow$ RCG/ Net energy}

Fig. 4. Energy ratio and net energy for potato and sugar beet compared with reed canary grass. $\mathrm{RCG}=$ Reed canary grass. NB the different scale of net energy in figures 3 and 4 . analysis a live weight of $105 \mathrm{~kg}$ was used, which corresponds to $61 \mathrm{~kg}$ of edible products. Fat, used for industrial purposes, is $9 \%$ of the living weight and the rest is considered waste (Lehto 2008). With fat included, the usable weight of the pig is $70 \mathrm{~kg}$. There are, however, also other parts from the carcass which can be utilized as industrial raw materials, for instance skin and bones, but these are not included in the calculations. The mean energy content of a pork is $9,4 \mathrm{MJ} \mathrm{kg}^{-1}$ (Fineli 2008). The energy amount in the pig carcass is $550 \mathrm{MJ}$ without fat and $890 \mathrm{MJ}$ when the industrial fat is included.

The energy used in feed production was $694 \mathrm{MJ}$ per pig and when energy used in housing (1068 MJ per pig) is added to this, the sum is $1762 \mathrm{MJ}$ per pig. This corresponded to 25-29 $\mathrm{MJ} \mathrm{kg}^{-1}$ energy usage per kilogram of produced meat (Table 6). Basset-Mens and van der Werf (Werf 2005) calculated fossil energy usage of 15.9-22.2 MJ kg-1. Cederberg and Darelius (2001) calculated energy usage of $22 \mathrm{MJ} \mathrm{kg}^{-1}$. The corresponding figure in Table 6 is $29 \mathrm{MJ} \mathrm{kg}^{-1}$, which is about $30 \%$ higher 
Vol. 18 (2009): 332-346.

Table 6. Energy consumption per produced kilogram of product at farm level. For pork production two figures are given depending on the utilization of fat.

\begin{tabular}{|c|c|c|c|}
\hline & \multicolumn{2}{|c|}{ Pork production, $\mathrm{MJ} \mathrm{kg}^{-1}$ meat } & \multirow{2}{*}{$\begin{array}{l}\text { Milk production, } \\
\mathrm{MJ} \mathrm{kg}^{-1} \text { milk }\end{array}$} \\
\hline & Bone and fatfree meat & Bonefree meat & \\
\hline $\begin{array}{l}\text { Calculated with feed production } \\
\text { energy consumption }\end{array}$ & 11 & 10 & 1.6 \\
\hline $\begin{array}{l}\text { Calculated with feed production } \\
\text { and housing energy consumption }\end{array}$ & 29 & 25 & 3.2 \\
\hline
\end{tabular}

than figures found in literature, largely because of the greater need for heating in the colder climate.

Energy consumption per produced kilogram of milk is also shown in Table 6. If the housing energy demand is not taken into consideration, then the figure is $1.6 \mathrm{MJ} \mathrm{kg}^{-1}$ milk and when it is included the ratio is $3.2 \mathrm{MJ} \mathrm{kg}^{-1}$ milk. Grönroos et al. (2006) calculated energy use in milk production for organic production $2.1 \mathrm{MJ} \mathrm{kg}^{-1}$ and for conventional production $4.1 \mathrm{MJ} \mathrm{kg}^{-1}$ milk when pre-farm and on-farm use was included and $87 \%$ of energy was allocated to milk production. Because the detailed figures are not available, the $0.9 \mathrm{MJ} \mathrm{kg}^{-1}$ higher consumption in conventional production is not possible to trace.

Refsgaard et al. (1998) analyzed production from 14 organic and 17 conventional farms and they determined energy usage as $2.2-3.6 \mathrm{MJ} \mathrm{kg}^{-1}$. The highest consumption was on irrigated sandy soils and the lowest in organic production. They included also meat production by converting it to milk production with a ratio of 10:1. Refsgaard et al. (2004) also included indirect energy usage, for instance in the case of buildings they used a figure of 3.4 GJ per cow and year. When this is added to the housing energy consumption of Table 6 , the ratio is 3.4 .

Thomassen et al. (2008) analyzed 10 conventional and 11 organic Dutch farms and they calculated in organic farms $3.1 \mathrm{MJ} \mathrm{kg}^{-1}$ milk and in conventional farms 5.0 $\mathrm{MJ} \mathrm{kg}^{-1}$ milk. They included both direct and indirect energy usage and the portion allocated to milk production was $91 \%$ for conventional and $90 \%$ for organic production. Carlsson (2004) analyzed the production of 23 western Sweden farms and determined for organic farms $2.1 \mathrm{MJ} \mathrm{kg}^{-1}$ milk and for conventional farms 2.7 $\mathrm{MJ} \mathrm{kg}^{-1}$ milk. She used in allocation $90 \%$ for milk and $10 \%$ for meat. The figures did not include buildings and machinery manufacturing energy. de Boer (2003) compared production figures from Sweden, Netherland and Germany and found that the energy use was $1.2-3.9 \mathrm{MJ} \mathrm{kg}^{-1}$.

The energy ratios vary in pork production between $0.14-1.28$ depending on what is included or excluded in the calculations and for milk production the ratio varies between $0.15-1.85$ (Table 7). Ratios of 1.28 in pork production and 1.85 in milk production are unrealistic as they do not give any shelter to the animals, although they can be approached in very low-input production systems. If the ratio is calculated with feed energy content then the ratio is low, $0.14-0.22$ for pork and 0.15 for milk, showing that the animals can convert 14-22 $\%$ percent of the input energy to usable product. Alternatively the input can be calculated as total energy used in the feed production and the energy used during the production, and then the energy ratio is 0.31 and 0.93 . In milk production the energy ratio of 0.93 means there is almost as much energy from the milk as is used in the production. Because building construction and machinery manufacturing energy is not included in the analysis, these ratio figures are optimistic and in reality they are lower. 


\section{Mikkola, H. J. \& Ahokas, J. Energy ratios in Finnish agricultural production}

Table 7. Energy ratios in pork and milk production at farm level calculated with different system boundaries. For pork production two figures are given depending on the utilization of fat.

\begin{tabular}{llccc}
\hline \multirow{2}{*}{ Output } & \multicolumn{3}{c}{ Input } \\
\cline { 3 - 5 } & & $\begin{array}{c}\text { Feed material caloric } \\
\text { value }\end{array}$ & $\begin{array}{c}\text { Feed production energy } \\
\text { consumption }\end{array}$ & $\begin{array}{c}\text { Feed production and housing } \\
\text { energy consumption }\end{array}$ \\
\hline \multirow{2}{*}{ Pig } & Bone and fat free meat & 0.14 & 0.79 & 0.31 \\
& Bone free meat & 0.22 & 1.28 & 0.51 \\
Cow & Milk & 0.15 & 1.85 & 0.93 \\
\hline
\end{tabular}

In pork production, the largest portion of the energy input is the ventilation of the building, i.e. the heat which flows from the building with the ventilated air (Fig. 5). It requires more energy than the production of the feed material. In order to keep the content of harmful gases and air humidity low, ventilation must be efficient, but this needs a lot of energy if heat recovery systems are not utilised. The analysis is sensitive to ventilation rate, the rate used for pork production in calculations

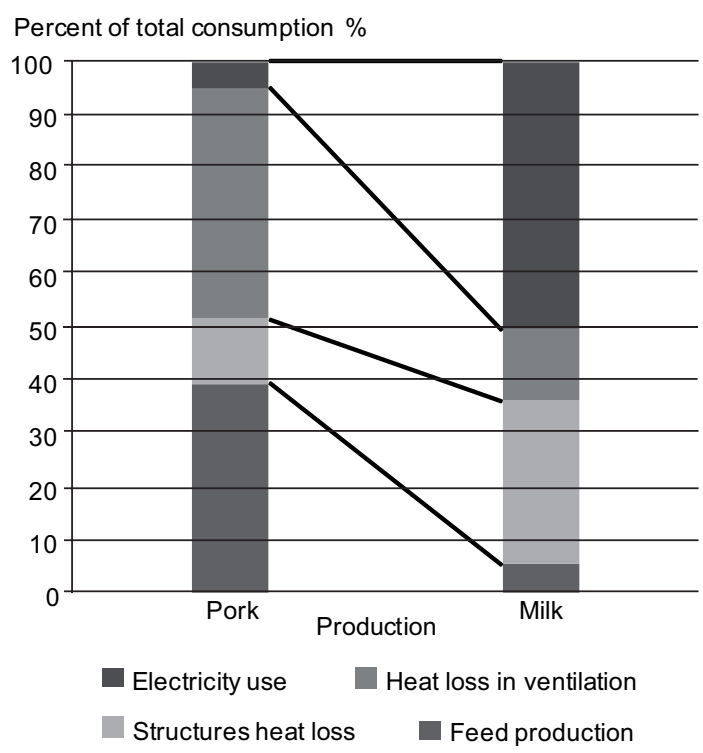

Fig. 5. Portions of energy consumptions in pork (total $1762 \mathrm{MJ}$ per pig) and milk production (total $27.3 \mathrm{GJ}$ per cow and year). corresponds to about $1500 \mathrm{ppm}$ of $\mathrm{CO}_{2}$ content and $25 \mathrm{~m}^{3} \mathrm{~h}^{-1}$ per pig. If the ventilation rate is increased to $50 \mathrm{~m}^{3} \mathrm{~h}^{-1}$ per pig , then the $\mathrm{CO}_{2}$ content is about $900 \mathrm{ppm}$ and the energy consumption is $36-42 \mathrm{MJ}$ $\mathrm{kg}^{-1}$ (feed production + housing) instead of 25-29

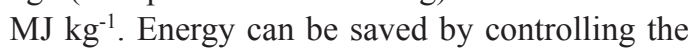
ventilation, but at the same time the microclimate is also controlled and this effects on animal welfare.

Fig. 5 shows also energy consumption portions in milk production. Because a cow produces more heat than a pig and it also copes in lower temperatures, the portion of heat losses is lower than with pigs. Milking cows could be housed in cold buildings without difficulties and this would reduce energy consumption considerably and increase the energy ratios to 1.5 when energy needed for feed production and housing only is used in analyzes. Milk production (milking and cooling) consumes a lot of energy and for this reason the electricity portion in milk production energy consumption is high.

\section{Discussion}

The optimum energy ratio in plant production was gained with less nitrogen fertilization intensity than farmers use. For barley the optimal energy ratio was obtained between $50-75 \mathrm{~kg} \mathrm{ha}^{-1}$ and for wheat $75-100 \mathrm{~kg} \mathrm{ha}^{-1}$, whereas agronomic practice is $80-100 \mathrm{~kg} \mathrm{ha}^{-1}$ for barley and $100-120 \mathrm{~kg} \mathrm{ha}^{-1}$ 
Vol. 18 (2009): 332-346.

for for wheat. Barley and wheat were shown to be more energy efficient crops and produced higher net energy yield than turnip rape. Seeds of turnip rape have a higher heating value than barley or wheat but it does not compensate for the low biomass. The curves of energy ratio for these three crops were quite steady between $50-150 \mathrm{~kg} \mathrm{~N} \mathrm{ha}^{-1}$ and farmers operate within this range in practice. However, high energy ratio is only one factor indicating well balanced farming practice. Farmers prefer the economical optimum to the energetic optimum, when they decide on fertilizer use. It must be also remembered that the nitrogen response functions were determined on fertile soils and prolonged low fertilization on poor soils could lead to lower yields.

If the original nitrogen response functions had been used instead of scaled functions for barley, wheat and spring turnip rape, energy ratios would have been two times higher at low nitrogen fertilization intensity. The optimum energy ratio would have been located at zero fertilization and net energy yields would have increased $60-200 \%$ - mostly at low fertilization levels.

For reed canary grass and grass ley the optimum energy ratio was gained with zero fertilization. Nitrogen application impaired the ratio especially for reed canary grass. With zero fertilization, the energy ratio for reed canary grass was 3-4 times the ratio for barley, wheat and turnip rape. In practice, cropping without fertilization would impoverish the soil within a few years and for this reason a modest annual fertilization is justified. However, the current recommendation of $90 \mathrm{~kg} \mathrm{~N} \mathrm{ha}^{-1}$ is high from the energetic point of view. A low cropping intensity would favor better a high energy ratio.

The energy ratio of ley reacted less to $\mathrm{N}$ fertilization than the ratio of reed canary grass. This follows from the good nitrogen response of ley. Ley produces higher net energy than barley, wheat and spring turnip rape. However, as an energy crop it remains poorer than reed canary grass. Crop straw is not presently utilized and the energy of this biomass is lost, with ley the whole biomass is used. Growing grasses as a mixture with clover or some other nitrogen fixing legume would increase net energy thanks to reduced nitrogen fertilization requirements.
Potato showed the same energy ratio and 20$40 \%$ higher net energy than barley and wheat. Sugar beet was even more effective as an energy plant than potato. The energy ratio was nearly two times higher and net energy on the same level as for reed canary grass. Perhaps the national yield statistics are anyway unfavorable for potato because potato is grown at all latitudes and by farmers of various levels of expertise, whereas sugar beet is grown by fewer farmers on the most favorable soil and climate conditions in south-western Finland. It is also relevant that at the end of the assessed harvesting chains, the yield of potato and sugar beet crops were piled in a clamp at the edge of a field and their moisture content was $77-78 \%$. In the best case a safe storage period would be 1-2 months at most, while the other crops could be stored for at least a year without outstanding storage losses - barley, wheat, spring turnip and reed canary grass even much longer. Processing of potato and sugar beet should take place in a short period of time otherwise they need a climate-controlled store building consuming more energy. Another notable factor is that potato and sugar beet are demanding crops that can be grown successfully only on the best fields, whereas reed canary grass and ley are in this respect much less demanding.

Reduced tillage methods resulted in higher energy ratios than ploughing. Green house gas emissions were not assessed in this study, but reduced tillage methods have also proved to conserve soil carbon, which is in many cases a much more important environmental factor than emissions from fuel used in machines.

In pork and milk production energy consumption varies widely mainly due to the choice of analytical method, the included and excluded parameters and also the allocation of production. Furthermore the production type has an effect on energy consumption, with lower inputs in organic and higher figures for intensive production. Other inputs can also increase the figures considerably, for instance irrigation or usage of dried grass, and the production type and geographical location has an effect on the figures, but the magnitude of the figures remains the same. In Finnish conditions the heating demand during winter consumes en- 


\section{Mikkola, H. J. \& Ahokas, J. Energy ratios in Finnish agricultural production}

ergy and the energy efficiency is not as good as in milder climates.

\section{Conclusions}

The highest energy ratio was 18.6 for reed canary grass with zero fertilization. Reed canary grass was in this respect superior to the other crops assessed. Sugar beet produced a high net energy yield but the energy ratio was lower than that for reed canary grass. The energy ratio of potato was below those of barley and wheat. The easy cultivation of reed canary grass and its tolerance to different soils and varying climatic conditions, makes this crop a high capacity energy plant. Cropping with zero fertilization is not realistic in the long term, but the current nitrogen fertilization recommendations of $80-90 \mathrm{~kg} \mathrm{ha}^{-1}$ are too high for a satisfactory energy ratio.

Energy ratios for barley and spring wheat were both maximal at 5.0-5.5, and the highest energy ratios for turnip rape were in the range 3.3-3.6. Spring turnip rape produces less biomass and it has higher heating value than barley and wheat, but the heating value does not compensate for the lower biomass. Energy ratio curves for these three crops are fairly flat and nitrogen fertilization has only a minor impact on these ratios in the range $50-150 \mathrm{~kg} \mathrm{ha}^{-1}$.

Ley is the most common crop in Finland and its energy ratio is equal to or better than those of barley, wheat, spring turnip rape and potato. Energy ratio of ley could be still higher if mixtures with legumes were used. Ley has a good nitrogen response and it produces fairly high net energy yields.

In Finnish animal husbandry conditions, the heating during winter consumes energy and the energy efficiency is not as good as in milder climates. Energy use can be reduced by favouring cold cow houses, and in pork production heat recovery systems would increase efficiency, but their usage depends on economic matters. Also the micro-climate demands have an effect on energy use and with lower temperatures energy could be saved if only this does not harm the animal welfare.

Energy analyses are in many cases hard to compare because there is no agreed standard method. Geographic and weather conditions have a great effect on the results as well as the choice of boundaries and allocations used in the analysis. The energy and LCA analysis would need an internationally accepted methods. de Boer (2003) stated that direct comparison of LCA studies is not possible because of differences in allocation or normative values. The authors suggest more international standardisation in the LCA methods.

Acknowledgements. The authors wish to thank The University of Helsinki and The Foundation of Marjatta and Eino Kolli for funding this research project.

\section{References}

Basset-Mens, C. \& van der Werf, H.M.G. 2004. Scenario based environmental assessment of farming systems: the case of pig production in France. Agricultural Ecosystems and environment 105: 127-144.

Börjesson, P.I.I. 1996. Energy analysis of biomass production and transportation. Biomass and Bioenergy 11: 305-318.

Carlsson, V. 2004. Kväveförluster och energianvändning på mjölkgårdar i västra Sverige. SIK- rapport 714.60 p. Available on the Internet: http://chaos.bibul.slu.se/sll/slu/ ex_arb_utf_vard/EHU192/EHU192.PDF. (In Swedish).

Cederberg, C. \& Darelius, K. 2001. Livscykelanalys (LCA) av griskött. Naturresursforum, Landstinget Halland. 53 p. Available on the Internet: http://www.regionhalland.se/ dynamaster/file_archive/041011/783f1b18fe599c66cafe b5ac66d3c7fc/Rapport\%20griskott.pdf. (In Swedish).

Conforti, P. \& Giampietro, M.1997. Fossil Energy Use in Agriculture: An International Comparison. Agriculture Ecosystems and the Environment 65: 231-243.

Danfors, B. 1988. Bränsleförbrukning och avverkning vid olika system för jordberabetning och sådd. Jordbrukstekniska Institutet, meddelande 420. 85 p. (In Swedish).

de Boer, I.J.M. 2003. Environmental impact assessment of conventional and organic milk production. Livestock Production Science 80: 69-77.

Edwards, R., Larivé, J.-F., Mathieu, V. \& Rouveirolles, P. 2006. Well-To-Wheels analysis of future automotive fuels and powertrains in the European context. Well-ToTank Report, Version 2b. Appendix 1, Description of individual processes and detailed input data. $81 \mathrm{p}$. Cited 6 June 2008. Available on the Internet: http://www. senternovem.nl/mmfiles/Well_to_Tank_Report_EU_ tcm24-195171.pdf. 


\section{AGRICULTURAL AND FOOD SCIENCE}

Vol. 18 (2009): 332-346.

Ermittlung des Kraftstoffverbrauchs in der Land- und Forstwirtschaft 2005. Österreichisches Kuratorium für Landtechnik und Landentwicklung. 5 p. Available on the Internet: http://www.weitau.at/data/OEKL_Kraftstoffverbrauch.pdf. (In Germany).

Fineli 2008. Finnish Food Composition Database. National Institute for Health and Welfare, Nutrition Unit. Database Release 9, February 19, 2008. Available on the Internet: http://www.fineli.fi/index.php?lang=en.

Giampietro, M. 2004. Multi-scale Integrated Analysis of Agroecosystems: An Integrated Assessment. CRC Press. $437 \mathrm{p}$.

Grönroos J., Seppälä J., Voutilainen P., Seuri P. \& Koikkalainen K. 2006. Energy usage in conventional and organic milk and rye bread production in Finland. Agriculture, Ecosystems and Environment 117: 109-118.

Grönroos J. \& Voutilainen P. 2001. Maatalouden tuotantotavat ja ympäristö, Inventaarioanalyysin tulokset. Suomen ympäristökeskuksen moniste 231. 63 p. Available on the Internet: http://www.ymparisto.fi/download. asp?contentid=15182. (In Finnish).

Helsel, Z.R. 1992. Energy and alternatives for fertilisers and pesticide use. In: Fluck, R.C., (ed.). Energy in farm production. Vol. 6. In: Stout, B.A., (ed.). Energy in world agriculture. Amsterdam: Elsevier; 1992. 367 p.

Hiivola, S.-L., Huokuna, E. \& Rinne, S.-L. 1974. The effect of heavy nitrogen fertilization on the quantity and quality of yields of meadow fescue and cocksfoot. Annales Agriculturae Fenniae 13: 149-160.

Hildén, M., Huhtala, A., Koikkalainen, K., Ojanen, M., Grönroos, J., Helin, J., Isolahti, M., Kaljonen, M., Kangas, A., Känkänen, H., Puustinen, M., Salo, T., Turtola, E. \& Uusitalo, R. 2007. Verotukseen perustuva ohjaus maatalouden ravinnepäästöjen rajoittamisessa. Ympäristöminiseriön raportteja 15. 73 p. (In Finnish).

Hörndahl, T. 2007. Energiförbrukning i jordbrukets driftsbyggnader - en kartläggning av 16 gårdar med olika driftsinriktning. Rapport 145. Sveriges lantbruksuniversitet, Institution för jordbrukets biosystem och teknologi (JBT). 40 p. Available on the Internet: http:// www.jbt.slu.se/publikationer/rapport/Rapport-145.pdf. (In Swedish)

Kalk, W.-D. \& Hülsbergen, K.-J. 1999. Dieselkraftstoffeinsatz in der Pflanzenproduktion. Landtechnik 54: 332333. (In Germany).

Katajajuuri, J.-M., Loikkanen, T., Pahkala, K., Uusi-Kämppä, J., Voutilainen, P. , Kurppa, S., Laitinen, P., Mikkola, H. J., Kivinen, T. \& Salo, S. 2000. Ympäristöhallintaa tukevan tietopohjan kehittäminen osana maatilojen laatujärjestelmää: Case: Rehuohran elinkaariarviointi. VTT tiedotteita 2034. 134 p. Available on the Internet: http://www.vtt.fi/inf/pdf/tiedotteet/2000/T2034. pdf. (In Finnish).

Katajajuuri, J.-M., Voutilainen, P., Tuhkanen, H.-R. \&Honkasalo, N. 2003. Elovena-kaurahiutaleiden ympäristövaikutukset. Maa- ja elintarviketalous 33: 47 p. Available on the Internet: http://www.mtt.fi/met/pdf/met33. pdf . (In Finnish).

Lehto M. 2008. Opas pienteurastamon sivutuotteiden hyödyntämisestä ja hävittämisestä. Ruoka-Suomi teemaryhmän julkaisu 1/2008. 19 p. (In Finnish).

Lindh, T., Kärki, J., Impola, R., Paappanen, T., Leino, T., Kallio, E., Rinne, S., Lötjönen, T. \& Kirkkari, A.-M. 2007.
The development of reed canary grass fuel chain. In: Mia Savolainen (ed.). Bioenergy 2007, 3.-6.9.2007: Book of proceedings. FINBIO publication 36: 329-336.

Lötjönen. T. 2008. Harvest losses and bale density in reed canary grass (Phalaris arundinacea L.) spring-harvest. Aspects of Applied Biology 90: 263-268.

Mäkinen, T., Soimakallio, S., Paappanen, T., Pahkala, K.\& Mikkola, H. J. 2006. Liikenteen biopolttoaineiden ja peltoenergian kasvihuonekaasutaseet ja uudet liiketoimintakonseptit. VTT tiedotteita 2357: 134 p. Available on the Internet: http://www.vtt.fi/inf/pdf/tiedotteet/2006/ T2357.pdf. (In Finnish).

McLaughlin, N.B., Drury, C.F., Reynolds, W.D., Yang, X.M., Li, Y.X., Welacky, T.W. \& Stewart, G. 2008. Energy Inputs for Conservation and Conventional Primary Tillage Implements in a Clay Loam Soil. Transactions of the ASABE 51: 1153-1163.

Mikkola, H. \& Ahokas, J. 2008. Indirect energy input of agricultural machinery in energy analysis. Proceedings $C D$ of AgEng2008 Conference. Hersonissos, Crete 23-25 June 2008, Greece. 15 p.

MMM-RMO 2002. Liitteet C1.2.1, C1.2.2, C2.1, C2.2, C3 ja C4. Cited 2009-06-05. Available on the Internet: http:// www.mmm.fi/fi/index/etusivu/maaseudun_kehittaminen/maaseuturakentaminen/rakentamissaadokset/rakentamissaadokset_lista.html. (In Finnish).

Moitzi, G., Refenner, K., Weingartmann, H. \& Boxberger, J. 2008. Kraftstoffverbrauch beim landwirtschaftlichen Transport. Landtechnik 63: 284-285. (In Germany).

MTT 2006. Rehutaulukot ja ruokintasuositukset 2006. MTT:n selvityksiä 106. 84 p. Available on the Internet: http://www.mtt.fi/mtts/pdf/mtts106.pdf . (In Finnish).

Palonen, J. \& Oksanen, E. H.1993. Labour, machinery and energy data bases in plant production. Työtehoseuran julkaisuja 330. $106 \mathrm{p}$.

Posio M. 2009. Maito- ja lihanautatilojen energiankäyttö. Kandidaatin tutkielma. Helsingin yliopisto, Agroteknologian laitos. 45 p. (In Finnish).

Refsgaard K., Halberg N., Kristensen E.1998. Energy utilization in crop and dairy production in organic and conventional livestock production systems. Agricultural Systems 4: 599-630.

Rinaldi, M., Erzinger, S., \& Stark, R. 2005. Treibstoffverbrauch und Emissionen von Traktoren bei landwirtschaftlichen Arbeiten. FAT-Schriftenreiche Nr. 65. 92 p. (In Germany).

Saijonkari-Pahkala, K. 2001. Non-wood plants as raw material for pulp and paper. Agricultural and Food Science in Finland 10, Supplement 1: 101 p. Helsingin yliopisto, (Doctoral Dissertation). Available on the Internet: http:// www.mtt.fi/afs/pdf/mtt-afsf10_suppl1.pdf.

Sieviläinen, E. 2008. Viljan laatuseuranta. [Available at The Finnish Food Safety Authority - EVIRA]. (In Finnish).

Suomi, P., Lötjönen, T., Mikkola, H., Kirkkari, A.-M., \& Palva, R. 2003. Viljan korjuu ja varastointi laajenevalla viljatilaIla. Maa- ja elintarviketalous 31. 100 p. (In Finnish9

Thomassen, M.A., van Calker, K.J., Smits, M.C.J., lepema, G.L.\& de Boer, I.J.M. 2007. Life cycle assessment of conventional and organic milk production in the Netherlands. Agricultural Systems 96: 95-107.

TIKE 2007. Yearbook of farm statistics 2007. Information Centre of the Ministry of Agriculture and Forestry, TIKE. 267 p. (In Finnish). 


\title{
Mikkola, H. J. \& Ahokas, J. Energy ratios in Finnish agricultural production
}

\begin{abstract}
Voutilainen, P., Katajajuuri, J.-M., Tuhkanen, H.-R. \& Honkasalo, N. 2003a. Kesäpöytä- Juustokermaperunoiden ja Pirkka-perunajauhon ympäristövaikutukset. Maa- ja elintarviketalous 34: 54 p. Available on the Internet: http://www.mtt.fi/met/pdf/met34.pdf. (In Finnish).

Voutilainen, P., Tuhkanen, H.-R., Katajajuuri, J.-M., Nousiainen, J.I. \& Honkasalo, N. 2003b. Emmental Sinileima -juuston tuotantoketjun ympäristövaikutukset ja parannusmahdollisuudet. Maa- ja elintarviketalous 35: 91 p. Available on the Internet: http://www.mtt.fi/met/pdf/ met35.pdf. (In Finnish).
\end{abstract}

West, T.O. \& Marland, G. 2002. A synthesis of carbon sequestration, carbon emissions, and net carbon flux in agriculture: comparing tillage practices in the United States. Agriculture. Ecosystems and Environment 91: 217- 232.

Ympäristöministeriö 2007. D5 Suomen rakentamismääräyskokoelma, Rakennuksen energiankulutuksen ja lämmitystehontarpeen laskenta, Ohjeet 2007. Ympäristöministeriö, Asunto- ja rakennusosasto. 72 p. Available on the Internet: http://www.finlex.fi/data/ normit/29520-D5-190607-suomi.pdf. (In Finnish).

\section{SELOSTUS}

\section{Suomalaisen maataloustuotannon energiasuhteet}

\author{
Hannu J. Mikkola and Jukka Ahokas
}

Helsingin yliopisto

Tutkimuksen tavoitteena oli laskea peltokasvituotannon energiasuhteet ja nettoenergia sekä kotieläintuotannon energiasuhteet Suomessa. Energiasuhde tarkoittaa suhdetta output/input ja nettoenergia erotusta output - input. Energiasuhteiden ja nettoenergian laskenta perustui kasvi- ja eläinlajikohtaisiin energia-analyyseihin. Kasvintuotannon energiasuhteet ja nettoenergia laskettiin sadolle annettavan lannoitetypen funktiona, koska maatalouskemikaalien osuuden todettiin olevan $54-73 \%$ sadon tuottamiseen tarvittavasta energiapanoksesta. Typen osuus oli siitä kaikkein suurin. Ruokohelven energiasuhde 18,6 oli korkein, ja kokonaisuutena ruokohelpi oli ylivoimainen verrattuna muihin analysoituihin kasveihin, jotka olivat ohra, kevätvehnä, rypsi, säilörehunurmi, peruna ja sokerijuurikas. Ruokohelpi ja sokerijuurikas saavuttivat korkeimmat nettoenergiasadot, 111-115 GJ ha ${ }^{-1}$. Korkeimmat energiasuhteet saavutettiin yleensä viljelijöiden käyttämiä typpilannoitusmääriä alemmilla lannoitusmäärillä.

Sianlihantuotannon energiasuhde oli $0,14-1,28$ riippuen siitä, mitä analyysiin otettiin mukaan ja mitä rajattiin ulos. Maidontuotannossa energiasuhde oli $0,15-1,85$. Korkeimmat energiasuhteet ovat kuitenkin epärealistisia Suomessa, koska ne edellyttäisivät, että eläimillä ei olisi lainkaan karjasuojaa. Tästä syystä niihin voidaankin päästä hyvin alkeellisessa tuotannossa. Kun energiasuhde laskettiin rehun energiasisällön mukaan, sianlihantuotannon energiasuhde oli $0,14-0,22$ ja maidontuotannon 0,15 . Eläin voi siis muuntaa $14-22 \%$ tuotantoon käytetystä energiasta käyttökelpoisiksi tuotteiksi. Sianlihantuotannossa kuluu runsaasti energiaa ilmanvaihtoon ja maidontuotannossa lypsämiseen ja maidon jäähdyttämiseen. Maidontuotannossa puolestaan sähkön kulutus on suuri. 